$\begin{array}{llllllllllllllll}\text { A C T A } & \text { C H E M I C A } & \text { S C A N D I N A V I C A } & 26 & (1972) & 611-623\end{array}$

\title{
A Study of the Mass Spectrometrical Fragmentation Patterns of 1,3,6-Triazacycl[3.3.3] azines*
}

\author{
OLOF CEDER and JOHANNAE. ANDERSSON \\ Department of Organic Chemistry, University of Göteborg and Chalmers Institute of \\ Technology, Fack, S-402 20 Göteborg 5, Sweden
}

\begin{abstract}
The mass spectrometrical fragmentation patterns of seven members of the 1,3,6-triazacycl[3.3.3]azine system, $8 a-g$, are discussed. Exact mass tables for the 2-methyl-substituted compounds $8 \mathrm{c}, 8 \mathrm{e}$, and $8 f$ provide the basis for the molecular composition assignments in the spectra of these compounds and of $8 a, 8 b, 8 d$, and $8 g$. In accord with the assumption that the system is aromatic, an abundance of doubly charged ions, the structures of which are discussed, was found the spectra.
\end{abstract}

Tn the preceding paper ${ }^{1}$ we have described the syntheses of seven members

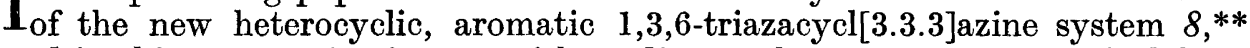
and in this communication we wish to discuss the mass spectrometrical fragmentation patterns of $8 a-g$ (and also of 4-cyano-2,8-dimethyl-1,3,6-triazacycl[3.3.3]azine, $8 h)$.

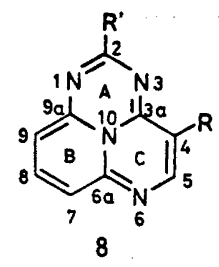

$\begin{array}{lll} & \mathbf{R} & \mathrm{R}^{\prime} \\ 8 a & \mathrm{H} & \mathrm{H} \\ 8 b & \mathrm{CN} & \mathrm{H} \\ 8 c & \mathrm{CN} & \mathrm{CH}_{3} \\ 8 d & \text { COOEt } & \mathrm{H} \\ 8 e & \text { COOEt } & \mathrm{CH}_{3} \\ 8 f & \mathrm{H} & \mathrm{CH}_{3} \\ 8 g & \text { COOMe } & \mathbf{H}\end{array}$

All seven compounds displayed, as could be anticipated from their aromatic structures, large molecular ion peaks. The spectra, with assignments, are reproduced in Figs. la-7a. Determinations of exact masses confirmed the assigned molecular formulas ( $c f$. also Table 1 in Ref. 1). The assignments of

\footnotetext{
* Presented in part at the "Second International Congress on Heterocyclic Chemistry" in Montpellier, July $7-12,1969$.

** The compounds bear the same numbers in this communication as in Ref. 1 .
}

Acta Chem. Scand. 26 (1972) No. 2 


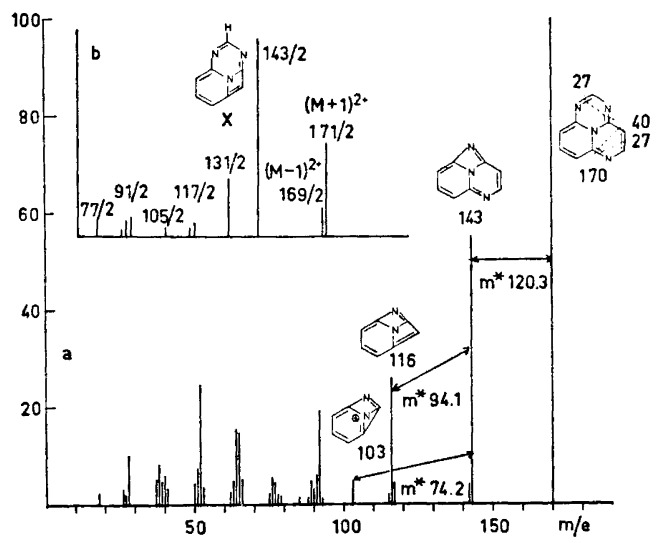

Fig. 1. Ion spectra of $8 a$, (a) singly charged; (b) doubly charged.

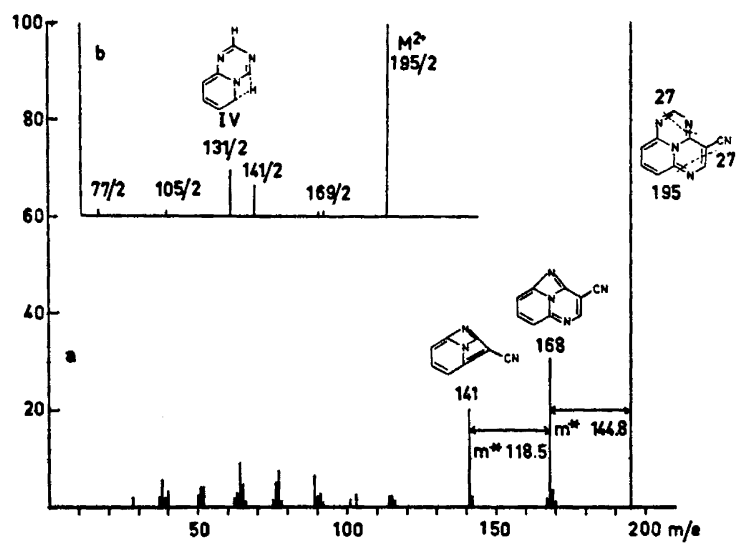

Fig. 2. Ion spectra of $8 b$, (a) singly charged; (b) doubly charged.

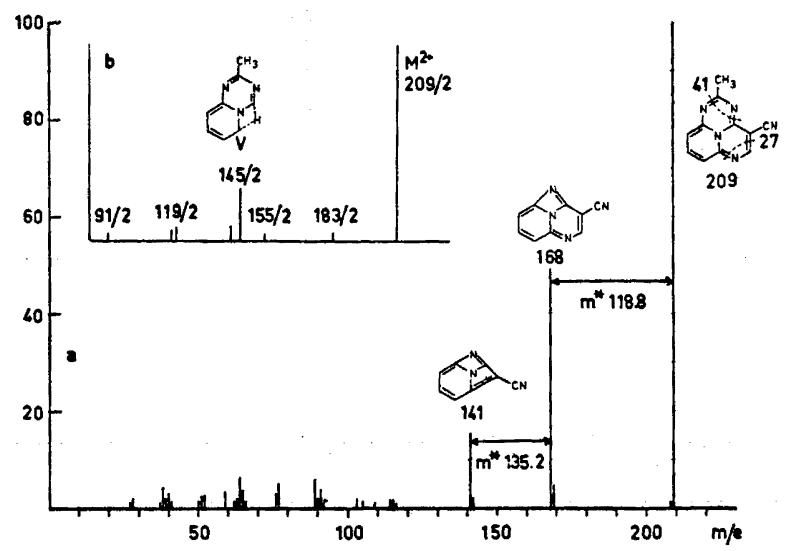

Fig. 3. Ion spectra of $8 c$, (a) singly charged; (b) doubly charged. 


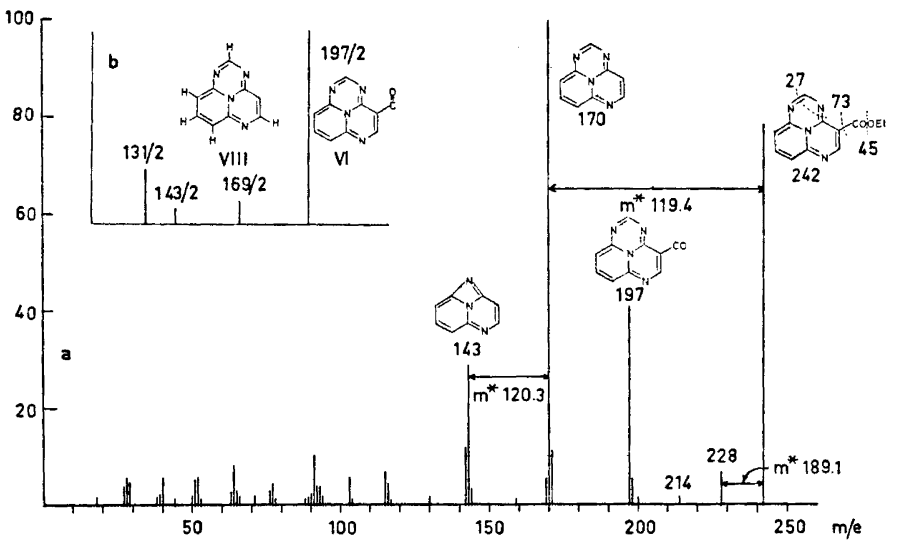

Fig. 4. Ion spectra of $8 d$, (a) singly charged; (b) doubly charged.

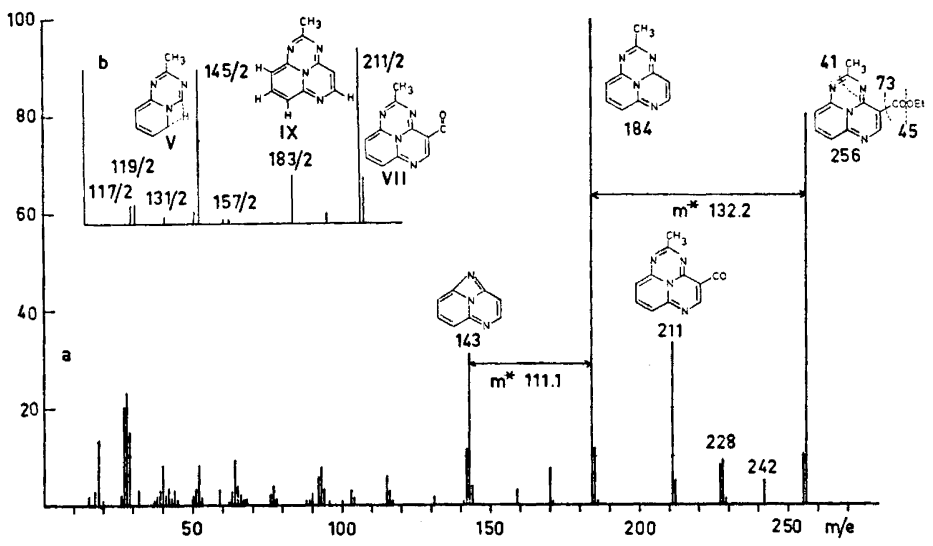

Fig. 5. Ion spectra of $8 e$, (a) singly charged; (b) doubly charged.

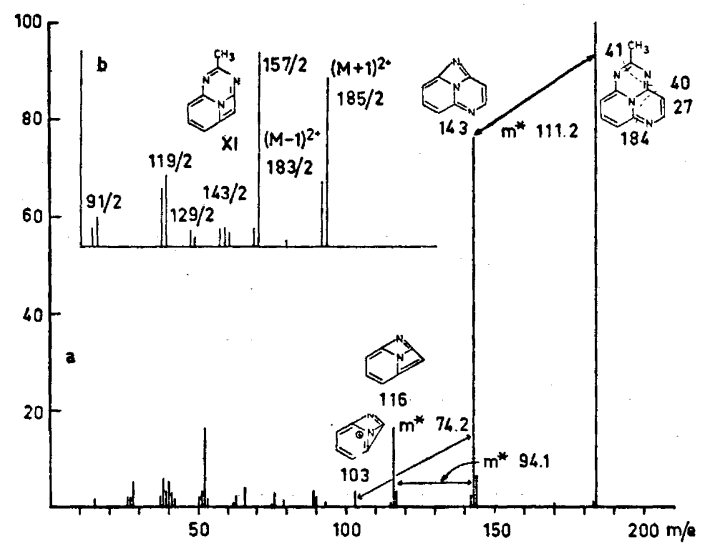

Fig. 6. Ion spectra of $8 f$, (a) singly charged; (b) doubly charged. 
molecular compositions of individual fragments proposed in Charts 1, 2, and 3 are based upon exact masses of "all fragments" in compounds $8 c, 8 e$, and $8 f$ ( $c f$. mass tables). The compositions of the fragments in the spectra of the norcompounds $8 a, 8 b, 8 d$, and $8 g$ are derived by analogy with the corresponding ions in the respective methyl homolog. A number of fragmentation paths are supported by the presence of metastable ions indicated in the spectra and in the charts.

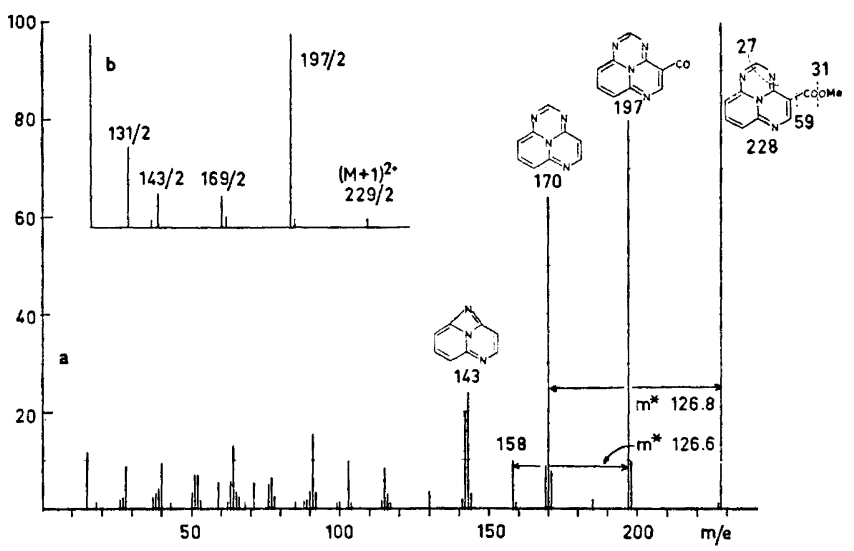

Fig. 7. Ion spectra of $8 g$, (a) singly charged; (b) doubly charged.

A major common fragmentation path in $\mathrm{N}$-heteroaromatic systems is the loss of HCN and, where a $C$-methyl group is adjacent to a ring nitrogen atom, of $\mathrm{CH}_{3} \mathrm{CN}$.* This type of fragmentation is observed in all seven compounds. In the spectra of $8 c$ and $8 f, 41$ and in the spectra of $8 a$ and $8 b, 27$ mass units are eliminated from the molecular ions, which are the base peaks in these spectra. In the 4-carbethoxy and 4-carbomethoxy derivatives this type of fragmentation is preceded by the loss of $\mathrm{COOC}_{2} \mathrm{H}_{5}+\mathrm{H}$ and $\mathrm{COOCH}_{3}+\mathrm{H}$, respectively, from the molecular ions to form base peaks at $m / e=170$ or 184 from which the elements of $\mathrm{HCN}$ or $\mathrm{CH}_{3} \mathrm{CN}$ are then eliminated. In all compounds these fragmentations are followed by a second loss of HCN to form the third most intense (above $m / e \sim 100$ ) peak at $m / e=116$ in the spectra of $8 a$ and $8 f$, and at $m / e=141$ in $8 b$ and $8 c$. The fact that $\mathrm{CH}_{3} \mathrm{CN}$ is the first fragment lost, where this is possible $\left(\mathrm{R}^{\prime}=\mathrm{CH}_{3}\right)$, leads to the proposal that the first elimination of HCN in the norcompounds $\left(R^{\prime}=H\right)$ involves $C-2$ and $N-1$ or $\mathrm{C}-2$ and $\mathrm{N}-3$, both possibilities giving rise to the same ion $\mathrm{I}$ ( $c f$. Charts 1,2 , and 3). The second mole of HCN lost would therefore be derived from C-5 and $\mathrm{N}-6$. In the cyano-substituted derivatives the fragments at $m / e=141$ could conceivably have the hetaryne structure $\mathrm{II},{ }^{3}$ resulting from an elimination of the cyano group and the adjacent H-5. This structure has the same molecular composition as III.

* This has been observed in a large number of systems, $f f$. Refs. $2-5$ in Ref. 2. 
<smiles>[R]c1cnc2cccc3nc1-n-2-3</smiles>

I<smiles>c1cc2nccc3nc(c1)-n-2-3</smiles>

II

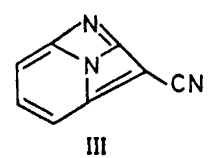

III

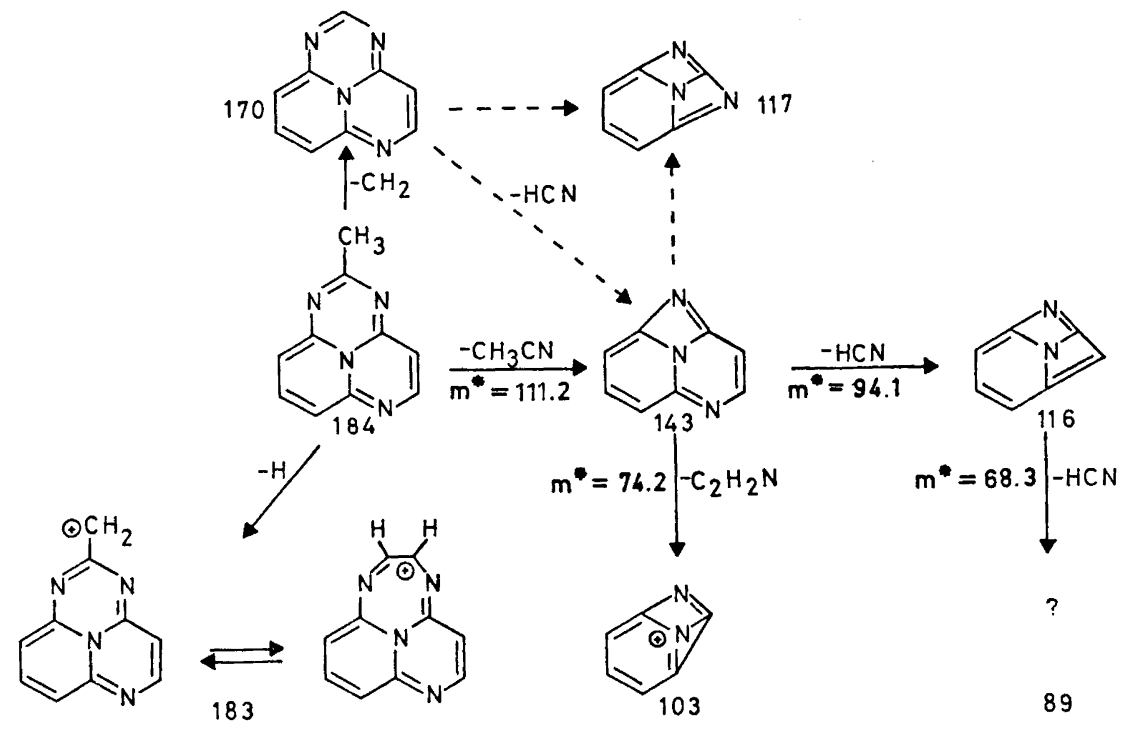

Chart 1. Fragments in the mass spectrum of $8 f$.

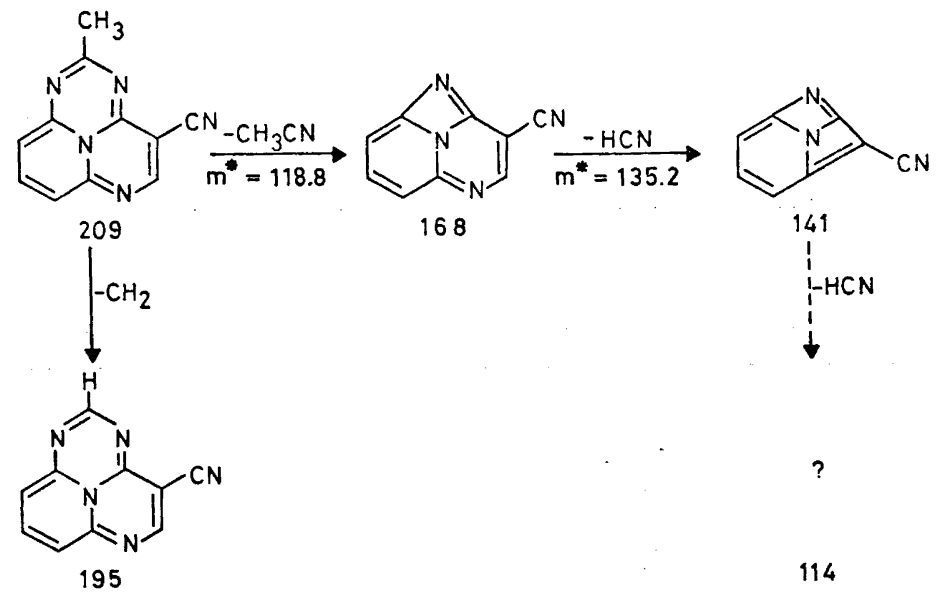

Chart 2. Fragments in the mass spectrum of $8 \mathrm{c}$.

Acta Chem. Scand. $26 \cdot(1972) \cdot$ No. 2 


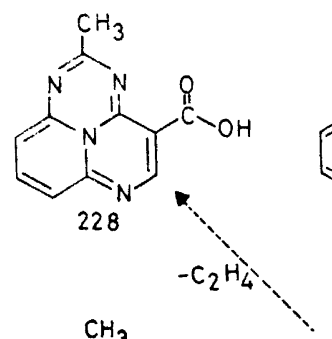

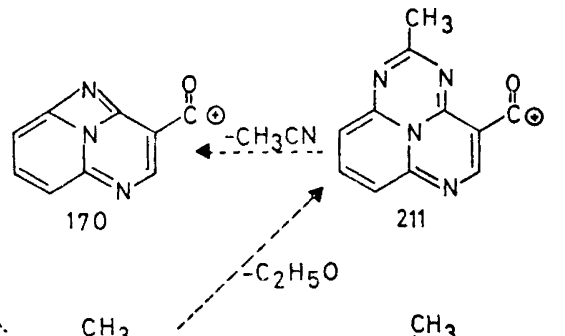<smiles>CCOC(=O)C1=CN=C2C=CC=C3N=C(C)N=C1N32</smiles><smiles>CCN(CC)C(=O)C1=CN=C2C=CC=C3N=C(C)N=C1N32</smiles><smiles>CC1=NC2=CC=CC3=NC=C(C=O)C(=N1)N23</smiles>

227

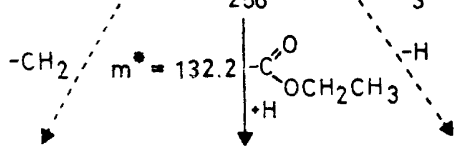<smiles></smiles><smiles>CC1=NC2=CC=CC3=NC=CC(=N1)N23</smiles><smiles>CCOC(=O)C1=CN=C2C=CC=C3N=C(CO)N=C1N32</smiles>

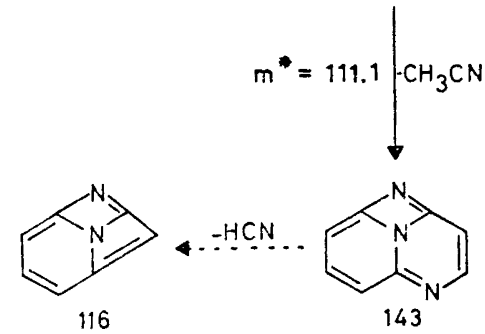<smiles></smiles>

Chart 3. Fragments in the mass spectrum of $8 e$.

The methyl-substituted compounds $8 c, 8 e$, and $8 f$ give rise to an $\mathrm{M}-1$ peak which could be stabilized in the following fashion. ${ }^{4}$ The carbethoxy, but<smiles>[R]c1cnc2nc([R])cnc3cccc(n1)-n-3-2</smiles>

Acta Chem. Scand. 26 (1972) No. 2 
Table 1. Accurate mass measurements in 2-methyl-1,3,6-triazacycl[3.3.3]azine ( $8 f)$.

\begin{tabular}{|c|c|c|c|}
\hline$m / e$ found & Formula & m/e calc. & $\Delta m / e$ \\
\hline 184.0748 & $\mathrm{C}_{10} \mathrm{H}_{8} \mathrm{~N}_{4}$ & 184.0749 & 0.0001 \\
\hline 183.0706 & $\mathrm{C}_{10} \mathrm{H}_{7} \mathrm{~N}_{4}$ & 183.0671 & 35 \\
\hline 170.0591 & $\mathrm{C}_{9} \mathrm{H}_{6} \mathrm{~N}_{4}$ & 170.0592 & 1 \\
\hline 143.0483 & $\mathrm{C}_{8} \mathrm{H}_{5} \mathrm{~N}_{3}$ & 143.0483 & 0 \\
\hline 117.0355 & $\mathrm{C}_{6} \mathrm{H}_{3} \mathrm{~N}_{3}$ & 117.0327 & 28 \\
\hline 116.0361 & $\mathrm{C}_{7} \mathrm{H}_{4} \mathrm{~N}_{2}$ & 116.0374 & 13 \\
\hline 115.0291 & $\mathrm{C}_{7} \mathrm{H}_{3} \mathrm{~N}_{2}^{2}$ & 115.0296 & 5 \\
\hline 103.0282 & $\mathrm{C}_{6} \mathrm{H}_{3} \mathrm{~N}_{2}$ & 103.0296 & 5 \\
\hline 93.0421 & $\mathrm{C}_{5} \mathrm{H}_{5} \mathrm{~N}_{2}$ & 93.0453 & 32 \\
\hline 90.0224 & $\mathrm{C}_{5} \mathrm{H}_{2} \mathrm{~N}_{2}$ & 90.0218 & 6 \\
\hline 89.0274 & $\mathrm{C}_{6} \mathrm{H}_{3} \mathrm{~N}$ & 89.0265 & 9 \\
\hline 89.0146 & $\mathrm{C}_{5} \mathrm{HN}_{2}$ & 89.0140 & 6 \\
\hline 79.0313 & $\mathrm{C}_{4} \mathrm{H}_{3} \mathrm{~N}_{2}$ & 79.0296 & 17 \\
\hline 78.0352 & $\mathrm{C}_{5} \mathrm{H}_{4} \mathrm{~N}^{2}$ & 78.0344 & 8 \\
\hline 78.0221 & $\mathrm{C}_{4}^{\circ} \mathrm{H}_{2}^{3} \mathrm{~N}_{2}$ & 78.0218 & 3 \\
\hline 77.0254 & $\mathrm{C}_{5} \mathrm{H}_{3} \mathrm{~N}$ & 77.0265 & 11 \\
\hline 76.0183 & $\mathrm{C}_{5} \mathrm{H}_{2} \mathrm{~N}$ & 76.0187 & 4 \\
\hline
\end{tabular}

Table 2. Accurate mass measurements in 4-cyano-2-methyl-1,3,6-triazacycl[3.3.3]azine $(8 c)$.

\begin{tabular}{clrr}
\hline$m / e$ found & Formula & $m / e$ calc. & $\Delta m / e$ \\
\hline 209.0705 & $\mathrm{C}_{11} \mathrm{H}_{7} \mathrm{~N}_{5}$ & 209.0701 & 0.0004 \\
195.0570 & $\mathrm{C}_{10} \mathrm{H}_{5} \mathrm{~N}_{5}$ & 195.0545 & 25 \\
169.0430 & $\mathrm{C}_{9} \mathrm{H}_{5} \mathrm{~N}_{4}$ & 169.0514 & 84 \\
168.0422 & $\mathrm{C}_{8} \mathrm{C}_{4} \mathrm{H}_{5} \mathrm{~N}_{4}$ & 169.0470 & 40 \\
167.0359 & $\mathrm{C}_{8} \mathrm{H}_{4} \mathrm{~N}_{4}$ & 168.0436 & 14 \\
142.0368 & $\mathrm{C}_{9} \mathrm{H}_{3} \mathrm{~N}_{4}$ & 167.0357 & 2 \\
& $\mathrm{C}_{8} \mathrm{H}_{4} \mathrm{~N}_{3}$ & 142.0405 & 37 \\
141.0313 & $\mathrm{C}_{7} \mathrm{CH}_{4} \mathrm{~N}_{3}$ & 142.0347 & 19 \\
114.0229 & $\mathrm{C}_{8} \mathrm{H}_{3} \mathrm{~N}_{3}$ & 141.0327 & 14 \\
103.0280 & $\mathrm{C}_{7} \mathrm{H}_{2} \mathrm{~N}_{2}$ & 114.0218 & 16 \\
92.0373 & $\mathrm{C}_{8} \mathrm{H}_{3} \mathrm{~N}_{2}$ & 103.0296 & 1 \\
91.0293 & $\mathrm{C}_{5} \mathrm{H}_{4} \mathrm{~N}_{2}$ & 92.0374 & 3 \\
90.0233 & $\mathrm{C}_{5} \mathrm{H}_{3} \mathrm{~N}_{2}$ & 91.0296 & 15 \\
89.0258 & $\mathrm{C}_{5} \mathrm{H}_{2} \mathrm{~N}_{2}$ & 90.0218 & 37 \\
77.0238 & $\mathrm{C}_{6} \mathrm{H}_{3} \mathrm{~N}^{2}$ & 89.0265 & 13 \\
77.0127 & $\mathrm{C}_{5} \mathrm{H}_{3} \mathrm{~N}$ & 77.0265 & 12 \\
76.0175 & $\mathrm{C}_{4} \mathrm{HN}_{2}$ & 77.0140 &
\end{tabular}

not the carbomethoxy, derivatives exhibit $M-14$ and $M-28$ peaks, which are absent in the spectra of all the other compounds. A likely explanation for these peaks is the ejection of $\mathrm{CH}_{2}$ and of $\mathrm{C}_{2} \mathrm{H}_{4}$, respectively, from the ethyl ester group in $8 d$ and $8 e$. These processes are supported by exact mass measurements for the fragments in $8 e$. That the $M-14$ peak at $m / e=242$ is not the 
Table 3. Accurate mass measurements in 4-carbethoxy-2-methyl-1,3,6-triazacycl[3.3.3]azine $(8 e)$.

\begin{tabular}{|c|c|c|c|}
\hline$m / e$ found & Formula & $m / e$ calc. & $\Delta m / e$ \\
\hline 256.0974 & $\mathrm{C}_{13} \mathrm{H}_{12} \mathrm{~N}_{4} \mathrm{O}_{2}$ & 256.0960 & 0.0014 \\
\hline 255.0896 & $\mathrm{C}_{13} \mathrm{H}_{11} \mathrm{~N}_{4} \mathrm{O}_{2}$ & 255.0882 & 14 \\
\hline 242.0808 & $\mathrm{C}_{12} \mathrm{H}_{10} \mathrm{~N}_{4} \mathrm{O}_{2}$ & 242.0804 & 4 \\
\hline 232.0949 & $\mathrm{C}_{11} \mathrm{H}_{12} \mathrm{~N}_{4}^{4} \mathrm{O}_{2}$ & 232.0960 & 11 \\
\hline 228.0608 & $\mathrm{C}_{11} \mathrm{H}_{8} \mathrm{~N}_{4} \mathrm{O}_{2}$ & 228.0647 & 39 \\
\hline 227.0525 & $\mathrm{C}_{11} \mathrm{H}_{7}^{\circ} \mathrm{N}_{4}^{2} \mathrm{O}_{2}$ & 227.0569 & 44 \\
\hline 214.0597 & $\mathrm{C}_{11} \mathrm{H}_{8} \mathrm{~N}_{3} \mathrm{O}_{2}$ & 214.0616 & 19 \\
\hline 212.0663 & $\mathrm{C}_{11} \mathrm{H}_{8}^{\circ} \mathrm{N}_{4} \mathrm{O}$ & 212.0698 & 35 \\
\hline 211.0638 & $\mathrm{C}_{11} \mathrm{H}_{7} \mathrm{~N}_{4} \mathrm{O}$ & 211.0620 & 18 \\
\hline 201.0763 & $\mathrm{C}_{10} \mathrm{H}_{9} \mathrm{~N}_{4} \mathrm{O}$ & 201.0776 & 13 \\
\hline 199.0632 & $\mathrm{C}_{10} \mathrm{H}_{7} \mathrm{~N}_{4} \mathrm{O}$ & 199.0619 & 13 \\
\hline 197.0852 & $\mathrm{C}_{11} \mathrm{H}_{8} \mathrm{~N}_{4}$ & 199.0827 & 25 \\
\hline 187.0593 & $\mathrm{C}_{8} \mathrm{H}_{7} \mathrm{~N}_{4} \mathrm{O}$ & 187.0620 & 27 \\
\hline 186.0779 & $\mathrm{C}_{11} \mathrm{H}_{10} \mathrm{~N}_{2} \mathrm{O}$ & 186.0793 & 14 \\
\hline \multirow[t]{2}{*}{186.0492} & $\mathrm{C}_{10} \mathrm{H}_{6} \mathrm{~N}_{2} \mathrm{O}_{2}$ & 186.0429 & 63 \\
\hline & $\mathrm{C}_{9} \mathrm{H}_{8} \mathrm{~N}_{6} \mathrm{O}$ & 186.0542 & 50 \\
\hline $\begin{array}{l}185.0792 \\
185.0441\end{array}$ & $\begin{array}{l}\mathrm{C}_{10} \mathrm{H}_{9} \mathrm{~N}_{4} \\
\mathrm{C}_{0} \mathrm{H}_{5} \stackrel{\mathrm{N}}{\mathrm{O}}\end{array}$ & $\begin{array}{l}185.0827 \\
185.0463\end{array}$ & $\begin{array}{l}35 \\
22\end{array}$ \\
\hline 184.1041 & $\mathrm{C}_{12} \mathrm{H}_{12} \mathrm{~N}_{2}$ & $\begin{array}{l}100.0400 \\
184.1000\end{array}$ & 41 \\
\hline 184.0756 & $\mathrm{C}_{10} \mathrm{H}_{8} \mathrm{~N}_{4}$ & 184.0749 & 7 \\
\hline \multirow[t]{2}{*}{184.0354} & $\mathrm{C}_{11} \mathrm{H}_{6} \mathrm{NO}_{2}$ & 184.0399 & 45 \\
\hline & $\mathrm{C}_{9} \mathrm{H}_{4} \mathrm{~N}_{4} \mathrm{O}$ & 184.0385 & 31 \\
\hline 183.0665 & $\mathrm{C}_{10} \mathrm{H}_{7} \mathrm{~N}_{4}$ & 183.0671 & 6 \\
\hline 177.0524 & $\mathrm{C}_{8} \mathrm{H}_{7} \mathrm{~N}_{3} \mathrm{O}_{8}$ & 177.0538 & 14 \\
\hline 171.0366 & $\mathrm{C}_{8} \mathrm{H}_{3} \mathrm{~N}_{4} \mathrm{O}$ & 171.0307 & 59 \\
\hline 170.0347 & $\mathrm{C}_{9}^{6} \mathrm{H}_{4} \mathrm{~N}_{3}^{2} \mathrm{O}$ & 170.0354 & 7 \\
\hline 167.0311 & $\mathrm{C}_{9} \mathrm{H}_{3} \mathrm{~N}_{4}$ & 167.0358 & 47 \\
\hline 160.0699 & $\mathrm{C}_{8}^{6} \mathrm{H}_{8} \mathrm{~N}_{2}^{*} \mathrm{O}$ & 160.0636 & 63 \\
\hline 160.0471 & $\mathrm{C}_{8}^{6} \mathrm{H}_{8}^{0} \mathrm{~N}_{3} \mathrm{O}$ & 160.0511 & 40 \\
\hline 160.0261 & $\mathrm{C}_{8} \mathrm{H}_{4} \mathrm{~N}_{2} \mathrm{O}_{2}$ & 160.0273 & 12 \\
\hline 159.0686 & $\mathrm{C}_{8}^{\circ} \mathrm{H}_{7}^{-} \mathrm{N}_{4}$ & 159.0671 & 15 \\
\hline 158.0579 & $\mathrm{C}_{8} \mathrm{H}_{6} \mathrm{~N}_{4}$ & 158.0592 & 13 \\
\hline 158.0334 & $\mathrm{C}_{8}^{\circ} \mathrm{H}_{4}^{\circ} \mathrm{N}_{3} \mathrm{O}$ & 158.0354 & 20 \\
\hline 157.0633 & $\mathrm{C}_{9} \mathrm{H}_{7} \mathrm{~N}_{3}$ & 157.0640 & $\mathbf{7}$ \\
\hline 152.0784 & $\mathrm{C}_{7} \mathrm{H}_{10} \mathrm{~N}_{3} \mathrm{O}$ & 152.0824 & 40 \\
\hline 151.0725 & $\mathrm{C}_{7} \mathrm{H}_{8} \mathrm{~N}_{3} \mathrm{O}$ & 151.0745 & 20 \\
\hline 150.0267 & $\mathrm{C}_{6} \mathrm{H}_{4} \mathrm{~N}_{3} \mathrm{O}_{2}$ & 150.0303 & 36 \\
\hline 149.0248 & $\mathrm{C}_{6} \mathrm{H}_{3} \mathrm{~N}_{3} \mathrm{O}_{2}$ & 149.0225 & 23 \\
\hline 144.0501 & $\mathrm{C}_{8} \mathrm{H}_{6} \mathrm{~N}_{3}$ & 144.0562 & 61 \\
\hline 143.0448 & $\mathrm{C}_{8}^{6} \mathrm{H}_{5}^{\circ} \mathrm{N}_{3}$ & 143.0483 & 35 \\
\hline 142.0375 & $\mathrm{C}_{8}^{\circ} \mathrm{H}_{4}^{\circ} \mathrm{N}_{3}$ & 142.0405 & 30 \\
\hline 141.0278 & $\mathrm{C}_{8} \mathrm{H}_{3} \mathrm{~N}_{3}$ & 141.0327 & 49 \\
\hline 134.0716 & $\mathrm{C}_{7} \mathrm{H}_{8} \mathrm{~N}_{3}$ & 134.0718 & 2 \\
\hline \multirow[t]{2}{*}{133.0548} & $\mathrm{C}_{6} \mathrm{H}_{5} \mathrm{~N}_{4}$ & 133.0514 & 34 \\
\hline & $\mathrm{C}_{8}^{6} \mathrm{H}_{7} \mathrm{NO}$ & 133.0528 & 20 \\
\hline 132.0512 & $\mathrm{C}_{7} \mathrm{H}_{6} \mathrm{~N}_{3}$ & 132.0562 & 50 \\
\hline 132.0266 & $\mathrm{C}_{7} \mathrm{H}_{4} \mathrm{~N}_{2} \mathrm{O}$ & 132.0324 & 58 \\
\hline \multirow[t]{2}{*}{131.0425} & $\mathrm{C}_{7} \mathrm{H}_{5} \mathrm{~N}_{3}$ & 131.0483 & 58 \\
\hline & $\mathrm{C}_{6} \mathrm{H}_{3} \mathrm{~N}_{4}$ & 131.0358 & 67 \\
\hline 130.0380 & $\mathrm{C}_{7} \mathrm{H}_{4} \mathrm{~N}_{3}$ & 130.0405 & 25 \\
\hline 128.0445 & $\mathrm{C}_{4} \mathrm{H}_{6} \mathrm{~N}_{3} \mathrm{O}_{2}$ & 128.0460 & 15 \\
\hline 120.0555 & $\mathrm{C}_{6}^{2} \mathrm{H}_{6} \mathrm{~N}_{3}$ & 120.0562 & 7 \\
\hline 116.0380 & $\mathrm{C}_{7}^{6} \mathrm{H}_{4}^{\circ} \mathrm{N}_{2}$ & 116.0374 & 6 \\
\hline
\end{tabular}

Acta Chem. Scand. 26 (1972) No. 2 
Table 3. Continued.
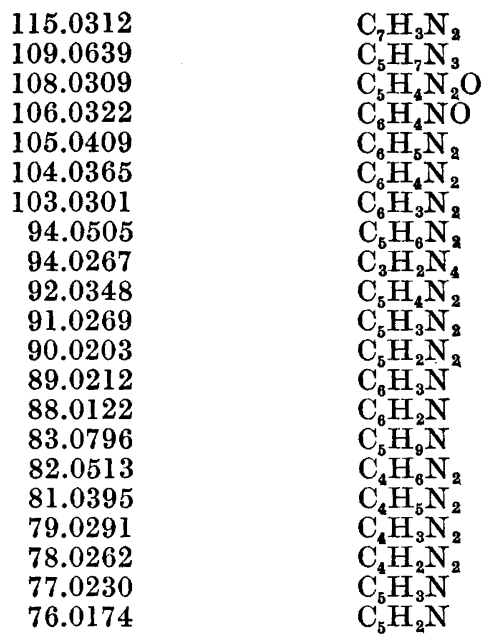

115.0296
109.0640
108.0324
106.0293
105.0453
104.0374
103.0296
94.0531
94.0279
92.0374
91.0296
90.0218
89.0265
88.0187
83.0735
82.0531
81.0453
79.0296
78.0218
77.0265
76.0187

16

15

29

31

9

26

12

26

27

15

53

65

61

18

58

5

44

35

13

result of a loss of $\mathrm{CH}_{2}$ from the methyl group at $\mathrm{C}-2$ is supported by analogous metastable peaks in the spectra of $8 e$ and $8 g$.

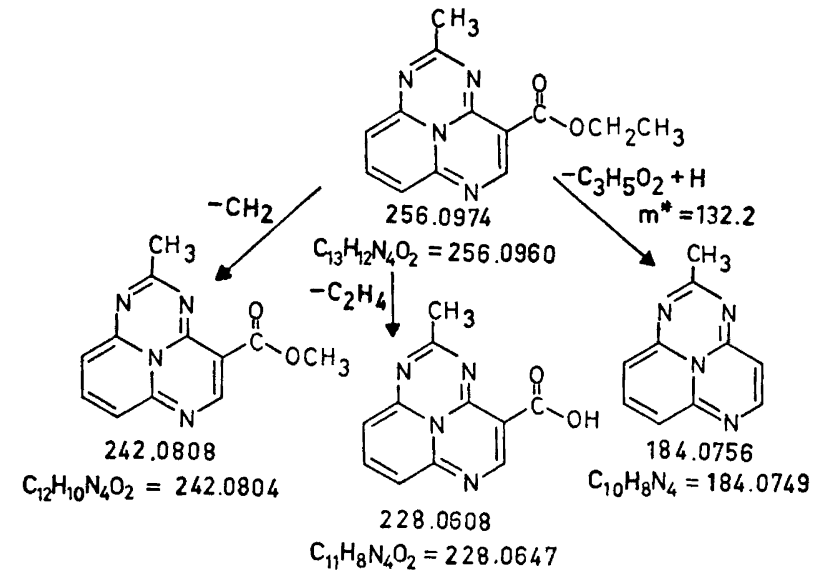

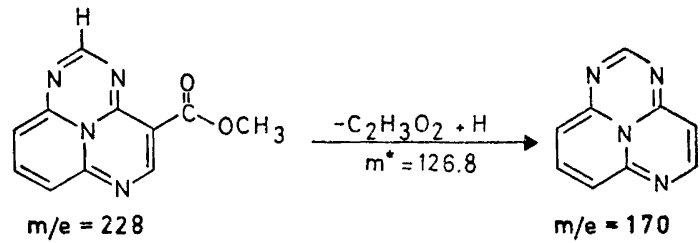

Acta Chem. Scand. 26 (1972) No. 2 
Some additional fragmentations and fragment structures are proposed in Charts 1, 2, and 3. All ions with $m / e>103$ seem to be derived from fragmentations of rings $A$ and $C$. For ions with $m / e=77-100$, no intensity pattern characteristic for all the compounds can be recognized, and no well-supported structures can be proposed. It seems reasonable to assume, however, that these fragments contain an intact $B$ ring (the original pyridine system). It has been observed ${ }^{5}$ that $\gamma$-picoline does not eject $\mathrm{CH}_{3} \mathrm{CN}$ to any considerable extent, and therefore we prepared the 8-methyl homolog of $8 \mathrm{c}$ from 2,6diamino-4-methylpyridine. We expected that in the spectrum of 4-cyano2,8-dimethyl-1,3,6-triazacycl[3.3.3]azine (Fig. 8), the ions corresponding to those in the $m / e=77-100$ region in the spectrum of $8 c$ would be displaced by 14 mass units. Fig. 8 shows that this is probably the case. Attempts to use the low resolution spectra of the 7-bromo, 9-bromo or 7,9-dibromo derivatives of $8 c^{6}$ for the same purpose were not successful since the first fragmentations in the spectra of these compounds result from the ejection of one or two atoms of bromine.*

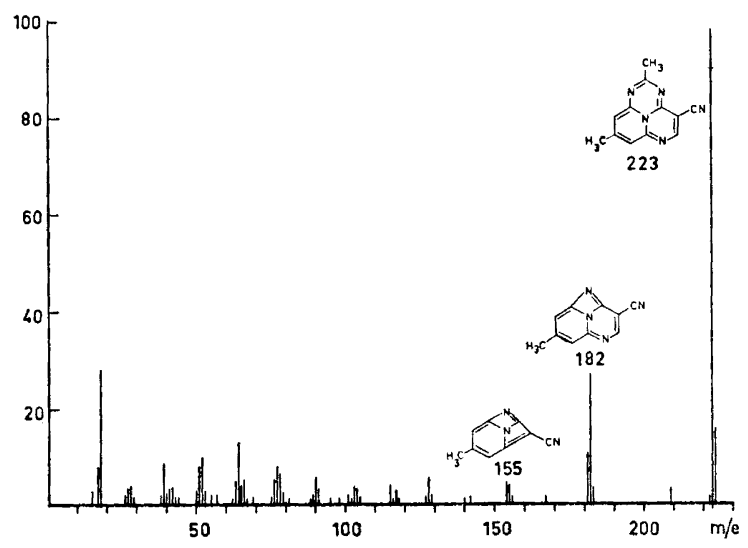

Fig. 8. Singly charged ion spectrum of $8 h$.

The resonance energies obtained from the HMO calculations ${ }^{1}$ indicated that the triazacyclazine system is aromatic, and this assumption is supported by the presence of abundant, doubly charged ions, the stability of which is increased when conjugated olefinic bonds and heteroatoms are present, particularly when they form $6 \pi$ electron (or $10 \pi$ electron, etc.) heteroaromatic systems. ${ }^{* *}$ In the doubly charged ion spectra of the 4-cyano cyclazine, $8 b$, and of its methyl homolog, $8 c$, the base peaks are represented by $\mathrm{M}^{2+}$, with intensities of 3 and $6 \%$, respectively, of the intensities of the corresponding singly charged molecular ions, which are also base peaks. The ions appearing at $m / e=131 / 2$ in the spectrum of $8 b$, and at $145 / 2$ in the spectrum of $8 c$, probably

*Cf. Ref. 11 in Ref. 6.

**Cf. Ref. 7 and further references therein. 
have structures IV and V, respectively (cf. Figs. $2 \mathrm{~b}$ and $3 \mathrm{~b}$ and Table 4 ). In the doubly charged ion spectra of the carbethoxy compounds $8 d$ and $8 e$, the base peaks at $m / e=197 / 2$ and $211 / 2$, respectively, probably possess structures VI and VII (cf. Figs. $4 b$ and $5 \mathrm{~b}$ and Table 5). The ions at $m / e=131 / 2$

Table 4. Accurate mass measurements in 4-cyano-2-methyl-1,3,6-triazacycl[3.3.3]azine $(8 c)$.

\begin{tabular}{rlrrr}
\hline$m / e^{2+}$ found & Formula & $m / e$ calc. & $m / e \times 0.5$ & $\Delta m / e$ \\
\hline 104.5341 & $\mathrm{C}_{11} \mathrm{H}_{7} \mathrm{~N}_{5}$ & 209.0701 & 104.5351 & 0.0010 \\
79.5285 & $\mathrm{C}_{7} \mathrm{H}_{5} \mathrm{~N}_{5}$ & 159.0545 & 79.5273 & 12 \\
72.5303 & $\mathrm{C}_{8} \mathrm{H}_{7} \mathrm{~N}_{3}$ & 145.0640 & 72.5320 & 17
\end{tabular}

Table 5. Accurate mass measurements in 4-carbethoxy-2-methyl-1,3,6-triazacycl[3.3.3]azine $(8 e)$.

\begin{tabular}{rlrrr}
\hline$m / e^{2+}$ found & Formula & $m / e$ calc. & $m / e \times 0.5$ & $\Delta m / e$ \\
\hline 128.0445 & & & & \\
105.0301 & $\mathrm{C}_{13} \mathrm{H}_{12} \mathrm{~N}_{4} \mathrm{O}_{2}$ & 256.0960 & 128.0480 & 0.0035 \\
92.0348 & $\mathrm{C}_{11} \mathrm{H}_{7} \mathrm{~N}_{4} \mathrm{O}$ & 211.0620 & 105.0310 & 9 \\
91.5285 & $\mathrm{C}_{10} \mathrm{H}_{8} \mathrm{~N}_{4}$ & 184.0749 & 92.0375 & 27 \\
72.5281 & $\mathrm{C}_{10} \mathrm{H}_{3} \mathrm{~N}_{4}$ & 183.0671 & 91.5336 & 49 \\
& $\mathrm{C}_{8} \mathrm{H}_{7} \mathrm{~N}_{3}$ & 145.0640 & 72.5320 & 39
\end{tabular}

and at $145 / 2$ (in $8 e$ only) may be represented, as in compounds $8 b$ and $8 c$, by structures IV and $V$, respectively, and for the ions at $m / e=169 / 2$ and $183 / 2$, respectively, structures VIII and IX are proposed. The presence of a fairly low-intensity $\mathrm{M}^{2+}$ ion in $8 e$ is proven by an exact mass measurement. For the carbomethoxy compound, $8 g$, the doubly charged ion spectrum (cf. Fig. $7 \mathrm{~b})$ is practically identical to that of $8 d$. An $(\mathrm{M}+1)^{2+}$ peak at $m / e=229 / 2$, not found in the spectrum of $8 d$, is observed for $8 g$. The doubly charged ion spectra of the parent cyclazine $8 a$, and of its methyl homolog, $8 f$ (cf. Figs. $1 \mathrm{~b}$ and $6 \mathrm{~b}$ and Table 6$)$, display base peaks at $m / e=143 / 2$ and

Table 6. Accurate mass measurements in 2-methyl-1,3,6-triazacycl[3.3.3]azine (8f).

\begin{tabular}{cllrr}
\hline$m / e^{2+}$ found & Formula & $m / e$ calc. & $m / e \times 0.5$ & $\Delta m / e$ \\
\hline \multirow{2}{*}{92.5405} & $\mathrm{C}_{10} \mathrm{H}_{9} \mathrm{~N}_{4}$ & 185.0827 & 92.5414 & 0.0009 \\
& $\mathrm{C}_{9}^{13} \mathrm{CH}_{9} \mathrm{~N}_{4}$ & 185.0783 & 92.5392 & 13 \\
92.0368 & $\mathrm{C}_{10} \mathrm{H}_{8} \mathrm{~N}_{4}$ & 184.0749 & 92.0375 & 7 \\
91.5367 & $\mathrm{C}_{10} \mathrm{H}_{7} \mathrm{~N}_{4}$ & 183.0671 & 91.5336 & 31 \\
78.5325 & $\mathrm{C}_{9} \mathrm{H}_{7} \mathrm{~N}_{3}$ & 157.0640 & 78.5320 & 5 \\
72.5341 & $\mathrm{C}_{8} \mathrm{H}_{7} \mathrm{~N}_{3}$ & 145.0640 & 72.5320 & 13 \\
71.5255 & $\mathrm{C}_{8} \mathrm{H}_{5} \mathrm{~N}_{3}$ & 143.0483 & 71.5242 &
\end{tabular}

Acta Chem. Scand. 26 (1972) No. 2 
$157 / 2$, respectively, corresponding to $(M-27)^{2+}$ and having structures $X$ and XI. No fragment formed by the loss of HCN from the molecular ion is present in the singly charged ion spectrum of $8 f$. Both $8 a$ and $8 f$ form large $(\mathrm{M}+1)^{2+}$ and $(\mathrm{M}-1)^{2+}$ ions, and for $8 f$, exact mass measurements ascertain an $\mathrm{M}^{2+}$ ion at $m / e=184 / 2$ of unknown, but low, intensity. It is unlikely that the ion at $m / e=185 / 2$ is derived from the ${ }^{13} \mathrm{C}$ isotope peak of the molecular ion, but an exact mass measurement does not distinguish it from $(M+1)^{2+}$ (cf. Table 6).

\section{EXPERIMENTAL}

General. Mass spectra were recorded with an LKB 900 mass spectrometer and exact mass determinations were made with a GEC-AEI 902 mass spectrometer. The mass tables were obtained with an Atlas MAT SMl instrument. Nuclear magnetic resonance spectra were recorded with a Varian Model A-60 spectrometer. Ultraviolet and visible spectra were measured in ethanol with a Cary 15 spectrophotometer. Infrared spectra were determined in $\mathrm{KBr}$ with a Beckman IR 9 spectrophotometer.

2,6-Diamino-4-methylpyridine. Using a procedure of Bernstein et al., ${ }^{8}$ somewhat modified, this compound was synthesized in the following way. To a solution of $20 \mathrm{~g}$ $(0.22 \mathrm{~mol})$ of $\gamma$-picoline in $40 \mathrm{~g}$ of $N, N$-dimethylaniline, $36 \mathrm{~g}(0.92 \mathrm{~mol})$ of sodium amide (50\% suspension in toluene) was added. The mixture, which turned black upon heating, was allowed to stand at $150^{\circ}$ for $17 \mathrm{~h}$, then at $190^{\circ}$ for $4 \mathrm{~h}$, and finally cooled to room temperature. The $N, N$-dimethylaniline was decanted off, the residual solid carefully decomposed with ice, and the resulting solution was extracted with three $300 \mathrm{ml}$ portions of isopropyl alcohol. The isopropyl alcohol solution was evaporated to dryness in vacuo, and the tarry residue was triturated with chloroform. The dark solid obtained was recrystallized three times from chloroform, yielding $2 \mathrm{~g}(7 \%$ ) of a white solid with m.p. (after sublimation at $65^{\circ} / 1$ torr) $103-104^{\circ}$ (lit. ${ }^{8} 109-111^{\circ}$ ); NMR (DMSO- $d_{6}$ ): $\delta=1.98$ (singlet, $3 \mathrm{H}, \mathrm{CH}_{3}$ ), 5.52 (singlet, $2 \mathrm{H}, \mathrm{H}-3$ and $\mathrm{H}-5$ ), and $5.08\left(4 \mathrm{H}, \mathrm{NH}_{2}\right.$ ).

Condensation of 2,6-diamino-4-methylpyridine with ethoxymethylenemalononitrile. To a solution of $220 \mathrm{mg}(1.79 \mathrm{mmol})$ of 2,6-diamino-4-methylpyridine in $22 \mathrm{ml}$ of benzene, $246 \mathrm{mg}$ ( $2.28 \mathrm{mmol})$ of ethoxymethylenemalononitrile was added and the mixture was refluxed for $24 \mathrm{~h}$. Upon cooling, a brown solid precipitated and was collected, dried and recrystallized from ethyl acetate-petroleum ether, yielding $230 \mathrm{mg}(64 \%$ ) of a light-brown crystalline solid, m.p. $204-205^{\circ}$; UV: $\lambda_{\max }$ at $235,272,285$, and $355 \mathrm{~nm}$; NMR (DMSO-d $\left.d_{6}\right): \delta=2.13$ (singlet, $3 \mathrm{H}, \mathrm{CH}_{3}$ ), 6.08 (singlet, $1 \mathrm{H}$ ), 6.23 (singlet, $1 \mathrm{H}$ ), 8.58 (singlet, $\left.1 \mathrm{H}, \mathrm{CH}=\mathrm{C}(\mathrm{CN})_{2}\right), 6.05$ (broad singlet, $\left.2 \mathrm{H}, \mathrm{NH}_{2}\right)$, and 11.25 (broad singlet, 1H, NH); MS: $\mathrm{M}^{+}=199$.

4-Cyano-2,8-dimethyl-1,3,6-triazacycl[3.3.3]azine. A mixture of $50 \mathrm{mg}(0.25 \mathrm{mmol})$ of the above condensation product, $0.3 \mathrm{ml}$ of acetic anhydride, and $2 \mathrm{ml}$ of glacial acetic acid was refluxed for $30 \mathrm{~min}$, cooled and evaporated to dryness in vacuo. Column chromatography on $5 \mathrm{~g}$ of silica gel with chloroform as the eluting agent gave $40 \mathrm{mg}(71 \%)$ of a violet crystalline solid. Further purification was accomplished by sublimation $\left(200^{\circ} / 1\right.$ torr), m.p. $292-293^{\circ}$; IR: $2220 \mathrm{~cm}^{-1}$; UV: $\lambda_{\max }$ at $212,240,263,330(\varepsilon=13380), 349,366$, $384,500,540,577(\varepsilon=468)$, and $623 \mathrm{~nm} ; \mathrm{NMR}$ (trifluoroacetic acid): $\delta=2.33$ (singlet, $3 \mathrm{H}, \mathrm{CH}_{3}$ at $\mathrm{C}-8$ ), 2.48 (singlet, $3 \mathrm{H}, \mathrm{CH}_{3}$ at $\mathrm{C}-2$ ), 6.72 (fine structure, $1 \mathrm{H}, \mathrm{H}-7$ or $\mathrm{H}-9$ ), 7.07 (fine structure, $1 \mathrm{H}, \mathrm{H}-7$ or $\mathrm{H}-9$ ), and 8.18 (singlet, $1 \mathrm{H}, \mathrm{H}-5$ ); $\mathrm{MS}$ : $\mathrm{M}^{+}=223.0848$ (calc. for $\mathrm{C}_{12} \mathrm{H}_{9} \mathrm{~N}_{5}=223.0858$ ).

Acknowledgements. The mass tables have been obtained from the Laboratory for Mass Spectrometry, Karolinska Institutet, Stockholm. We are indebted to Dr. R. Ryhage for this courtesy. The technical assistance of Mrs. Inger Nilsson is gratefully acknowledged. This work has been supported by grants from the Swedish Natural Science Research Council. 


\section{REFERENCES}

1. Ceder, O. and Andersson, J. E. Acta Chem. Scand. 26 (1972) 596.

2. Paudler, W. W., Kuder, J. E. and Helmick, L. S. J. Org. Chem. 33 (1968) 1379.

3. Budzikiewicz, H., Djerassi, C. and Williams, D. H. Mass Spectrometry of Organic Compounds, Holden-Day, San Franciseo 1967, p. 418.

4. $C f$. Ref. 3, p. 573.

5. Cole, W. G., Williams, D. H. and Yeo, A. N. H. J. Chem. Soc. 19681284.

6. Ceder, O., Andersson, J. E. and Johansson, L.-E. Acta Chem. Scand. 26 (1972) 624.

7. Vouros, P. and Biemann, K. Org. Mass Spectrom. 2 (1969) 375.

8. Bernstein, J., Stearns, B., Shaw, E. and Lott, W. A. J. Am. Chem. Soc. 69 (1947) 1151.

Received April 19, 1971. 